\title{
Evaluating the impact of land redistribution: A CGE microsimulation application to Zimbabwe ${ }^{1}$
}

\author{
Margaret Chitiga $^{* a}$, Ramos Mabugu ${ }^{\mathrm{b}}$ \\ ${ }^{a}$ Department of Economics, University of Pretoria, Pretoria 0002, South Africa \\ ${ }^{\mathrm{b}}$ Financial and Fiscal Commission, Midrand, South Africa
}

Zimbabwe has recently gone through a widely criticised land reform process. The country has suffered immensely as a result of this badly orchestrated reform process. Yet land reform can potentially increase average incomes, improve income distribution and as a consequence reduce poverty. This paper presents a counterfactual picture of what could have happened had land reform been handled differently. The paper uses a computable general equilibrium (CGE) model coupled with a microsimulation model in order to quantify the impact of land redistribution in terms of poverty, inequality and production. This is to our knowledge the first attempt to apply such an approach to the study of the impact of land reform on poverty and distribution in the context of an African country. The results for the land reform simulations show that the reform could have had the potential of generating substantial reductions in poverty and inequality in the rural areas. The well off households, however, would have seen a slight reduction in their welfare. What underpins these positive outcomes are the complementary adjustments in the fiscal deficit and external balance, elements that were generally lacking from the way Zimbabwe's land reform was actually executed. These results tend to suggest that well planned and executed land reforms can still play an important role in reducing poverty and inequality.

JEL Classification: D31, D63, D58, Q15

Keywords: Computable General Equilibrium, Land reform, Microsimulation, Poverty, Inequality.

\section{Introduction}

\footnotetext{
1 This work was carried out with the model built from a grant from the Poverty and Economic Policy (PEP) Research Network (www.pep-net.org), financed by the International Development Research Centre (IDRC). We received intensive data and technical assistance on the original work from Professors Bernard Decaluwe and John Cockburn, Dr Nabil Annabi and Mr. Ismael Fofana. Suggestions from an anonymous referee and the managing editor of this journal are gratefully acknowledged. Any errors remain our own.
}

* Corresponding author. Tel.: +27 12 4203457; fax: +27 123625207

Email address: margaret.chitiga@.up.ac.za. 
There are many authors that argue that land redistribution is good for growth (Birdsall and Londono (1997), Burgess and Beasly (1998), Deninger and Squire (1998) and Aghion (1999)). The World Development Report of 2001 argued that lower growth could be caused by inequality in the land ownership distribution (World Bank (2001)). Deninger et al (2000) show that land redistribution can reduce poverty and because it increases efficiency, it will lead to growth. The end of the 1990s marked the beginning of an era of deep and controversial land reforms in Zimbabwe. The government redistributed a substantial amount of the land owned by white farmers to black farmers in a very short time span in what has now come to be known as the fast track land reform. Prior to the fast track land reform, the "willing-seller-willing-buyer" principle directed government land reform. Given the slowness of the redistribution process achieved under the "willing-seller-willing-buyer" principle as well as the costs involved, the authorities revised their timescale and embarked on the fast track land reform. Contrary to the optimism found in the literature cited above concerning the benefits of land reform, the outcome for Zimbabwe has been dismal. Poverty rates and inequality have gone up substantially following the land reform. Far from hurting only commercial farmers who have lost farms, the economic decline has had widespread negative effects on the general population. Does this mean that Zimbabwe provides evidence that does not support most of the studies predicting beneficial impacts of land reform or could the mismanagement of the land reform process have contributed to the increase in poverty that is now associated with land reform?

There are a growing number of studies that have emphasized the political economy aspects of the Zimbabwean land reform. For instance, Moyo and Yeros (2004) argue that the land reform is an instance similar to a national democratic revolution while Davies (2004) argues that the reform has destroyed rather than created capital and has weakened the revolution. Zimconsult (2004) argues that poor planning and government's failure to move to restoring food security are not the only problems but also its use of food as a political weapon has negatively contributed to the outcome. As would be expected, there are no tangible data with which to evaluate these arguments so that emotions and confusion have surrounded this debate. Rather than continue with the debate along these lines, this paper reassesses the land reform programme in Zimbabwe with a particular focus on some very interesting economic questions that were largely ignored in the way the programme was executed and in the normal discourse over the effects of land reform. 
This paper intends to make two contributions to the literature on land reforms in Africa. Firstly, to make sense of the economic decline that has ensued in Zimbabwe, it would appear that the relevant question is what the outcome would have been had the government seriously committed to credible macroeconomic policies while carrying out the land reform exercise. This is a hypothetical question in the sense that the land reform program was administered in an atmosphere of high and growing macroeconomic imbalances and therefore requires the construction of a relevant counterfactual. There is likely to be disagreement over the relevant counterfactual. To increase transparency, the issue of a counterfactual is handled in this paper by constructing a model that assumes the maintenance of the pre-crisis macroeconomic structure. Secondly, drawing on recent poverty modelling literature, the paper presents a relatively new paradigm for analyzing the poverty impacts of land reforms in African economies. The insights from this literature are incorporated into a separate generic microsimulation model that is linked to a computable general equilibrium (CGE) model. The CGE model coupled with a microsimulation model is then used to quantify the impact of land redistribution in terms of poverty, inequality and production. Recent work in the CGE tradition that explores the consequences of land reform for Zimbabwe include the work of Bautista et al (1998, 2000), while Juana and Mabugu (2005) explore a similar issue using a Social Accounting Matrix (SAM) multiplier approach. The value added of the work carried out in this paper lies in the explicit poverty modelling accomplished through the use of microsimulation techniques linked to a CGE model. There is no parallel work in Zimbabwe and indeed in the rest of Africa that we are aware of that has applied this technique to land reform issues. $^{2}$

The rest of the paper is arranged as follows: section 2 briefly discusses the issues surrounding land reform in Zimbabwe while section 3 presents the model. Section 4 discusses the simulation implemented as well as the results. Section 5 concludes the paper.

\section{Background to land issues in Zimbabwe}

Zimbabwe inherited a prosperous agro-based economy at independence in 1980. However, the agricultural sector was dual in nature with the coexistence of a large-scale commercial (LSC) sector controlled by mainly white farmers, and a small-scale communal agricultural

\footnotetext{
${ }^{2}$ For recent microsimulation CGE models applied to trade issues, see for example Cockburn (2001) and Cororaton (2003).
} 
sector owned by the indigenous African people. Small scale agriculture was further divided into small scale commercial agriculture and communal agriculture. After independence, another sector consisting of resettled farmers was formed within the small scale agriculture sector. Although white farmers made up less than one per cent of the population, they controlled more than half of the productive land. Small scale farmers tended to practice mixed cropping of mainly non-export oriented crops and tended to use their land more intensively than large scale commercial farmers. Chiremba and Masters (2003) report the national-average cropping intensity of 1994 as 4 per cent for large scale commercial farmers, 11 per cent for communal farmers and 8 per cent for resettled farmers.

From the outset, Zimbabwe pursued a land acquisition strategy based on a 'willing-sellerwilling-buyer' principle along the lines agreed at the Lancaster House in 1979 during the country's independence negotiations. The government was the main buyer, having received grants approximately equal to US\$44 million during the 1980 s from Britain for land acquisition (Moyo (2004)). About 430,000 hectares were acquired each year between 1980 and 1986, falling to an average acquisition of 75,000 hectares per annum between 1985 and 1992 and approximately 158,000 hectares per year between 1992 and 1997 (Moyo (2004)). The acquired land was given to about 70,000 families against a target of 162,000 families for resettlement while white settler farmers land ownership had fallen from 50 per cent of agricultural land in 1980 to 29 per cent in 1986 (Moyo (1995)). The Lancaster House constitutional safeguards for market-based land transfers expired in 1990.

Starting in 1997 and largely led by war veterans, land seizures began. Government responded by formalizing the seizures in what came to be known as the compulsory land acquisition law, which was the defacto successor to the 'willing-seller-willing-buyer' principle. Another important development was the collapse of ongoing discussions over land reform between the government and the United Nations Development Program and the British Government in 2000 as this signaled the end of any hopes for a negotiated solution to the land crisis. The government announced that it would repossess 1471 commercial farms, which translated to more than 11 million hectares of land. This makes up about 40 per cent of the total commercial land (OECD (2003)). According to Moyo (2004), smallholder farmers' control of land had increased to 70 per cent of the land by 2003 while the area designated as commercial experienced a 42 per cent drop in land area. 
Before the onset of the fast track land reform, the agricultural sector employed a total of over 70 per cent of the labour force (Christiansen (1993)). Agriculture contributed between 9 per cent and 15 per cent to gross domestic product (GDP) and between 20 per cent and 33 per cent to export earnings. The sector was an important supplier of raw materials to the industrial sector, contributing 20 per cent of the manufacturing inputs in the eighties.

What has happened since then in terms of the economy is nothing short of a catastrophe. Real GDP growth has been negative since 2000, reaching -14.5 per cent in 2002, and projected at -12.4 per cent for 2003 (Matshe (2004)). According to Davies (2004), real income per head in 2004 was projected to be 46 per cent less than it was in 1996 based on government official data or 53 per cent less if data from the International Monetary Fund were used. According to CIA (2007), the population below the poverty line was estimated at 80 per cent in 2004, while the Gini index was estimated at 56.8 for 2003. These statistics are markedly higher than those reported in CIA (1998) showing that the population below the poverty line was estimated to be 25.5 per cent between 1990 and 1991. CIA (2004) reported that the population below the poverty line was estimated at 70 per cent in 2002 and the Gini index was 50.1 for 1995 . These statistics show that poverty and inequality increased substantially between the period 1990 and 2004. Chitiga and Mabugu (2005) report that poverty levels have likely continued to rise since 2000, largely driven by the dismal macroeconomic performance, drying up of important external aid inflows and high inflation (largely a result of supply shortages (due in part to reduced agricultural farming activity and droughts) and huge budget deficits)). Given the high inflation rates that have characterized the economy since 1997 and the massive job losses, it is not surprising that income distribution has not improved during the period.

It is not easy to isolate and quantify the effects of the fast track land reform because of the many interactions that took place (for example weather, international "sanctions", governance and bad economic policies and outcomes). There is need to develop a picture of what could have happened had land reform been carried out without these disturbances. The argument that is explored in this paper is based on a counterfactual and is premised on a contention that such suffering as was experienced in Zimbabwe could have been avoided had the land reform been done with due care being taken of the consequences for the fiscal and external deficit as well as other external shocks. 


\section{Empirical modelling framework}

This paper uses a Walrasian CGE model to present a counterfactual picture of what could have happened to the Zimbabwean economy following a well-executed land reform. The model is based on the EXTER+ model (see Decaluwé et al (1999), Cockburn and Cloutier (2002) and Cockburn et al (2004)). ${ }^{3}$ The focus is on the effects on poverty and inequality. The model is implemented using benchmark data from 1995, a date by which the fast track land reform had clearly not commenced. The details of the SAM are documented in Chitiga et al (2000). The year 1995 is arguably the last stable benchmark for the economy before the onset of the fast track land reform exercise and also coincides with available data from a household survey. For these reasons, 1995 was considered to be a suitable benchmark.

The model has 16 production sectors and activities. These are grain crops, horticulture crops, tea and coffee, cotton and tobacco, all other crops, livestock, fishery, forestry, mining, food processing, textile, all other manufacturing, construction, water, electricity and other trade services, public services and all other private services. Half of the sectors are agricultural based since the emphasis of the paper is on agricultural land. Typical to most other CGE models, the model does not distinguish production functions by household or farming group but according to sectors. Each sector's output is homogeneous. Assuming different production functions by type of farmer would require very detailed information on household production technology based on survey of production and would entail introducing heterogeneity at the producer level. This way of modelling production is not pursued in this paper because we do not have at our disposal a detailed production survey for the base year for the Zimbabwe model. There are 4 factors of production, namely, skilled labour, unskilled labour, capital and land. The sequential micro-model incorporates 14006 households. These households' incomes and expenditures are derived from the 1995 Poverty Assessment Study Survey (PASS) (Government of Zimbabwe 1996).

The model makes use of multi level nested production functions to determine production. Sectoral output is a Leontief combination of intermediate consumption and value added. Similarly, intermediate demand by sectors is modeled using Leontief functions. Value added is modelled as a constant elasticity of substitution (CES) aggregation of capital and labour. In

\footnotetext{
${ }^{3}$ Some of the published CGE evaluations applied to Zimbabwe include Davies et al $(1994,1998)$, Rattsø and Torvik (1998), Chitiga (2000) and Mabugu (2001).
} 
the agricultural sector, land is included in the CES function between the composite factor (capital and labour) and land. The model distinguishes two labour categories of skilled and unskilled labour types and specifies a CES function to capture the relationship between them. It is assumed that there are given factor endowments. Capital and labour are freely mobile across the sectors so that wages for each skill type and return on capital are the adjusting variables clearing the capital and labour markets.

Next it is assumed that there are four types of institutions corresponding to households, government, firms and the rest of the world. The CGE model contains five household groups divided according to their labour use, their farming structure and whether they are urban or rural based. The five household types are as follows: communal farmers, commercial farmers (who include large scale and small scale farmers), farm workers, urban unskilled income earners and urban skilled income earners. The first two groups are rural based, derive a large part of their income from land and are assumed to be the only land owners in the model. The third group is also rural based and derives most of its income from unskilled employment supplied at the farms. The last two groups are urban based, the fourth one deriving its main labour income from unskilled employment and the fifth from skilled employment. In addition, households can also earn income from capital and transfers from each other, from the rest of the world and from the government. Capital pays mainly the urban skilled income earners and the rural commercial farmers. Commercial farmers in addition also derive substantial income from skilled employment. This is income earned by farm owners who are usually also farm managers. These five types of households are representative of the micromodel in which all households from a survey are included. We thus map the results from the CGE model to the micro model after a simulation according to the group in which each household belongs. This micro-model distinguishes 14006 households that fit into one of each of the five household groups.

Table 1 shows the factor income shares of the different households. They spend their income on payment of taxes, transfers to other institutions and savings to remain with disposable income. The households allocate their disposable income to sectoral consumption by maximising a Stone Geary type utility function taking prices as given. It is assumed that household savings propensities are fixed and calibrated from the SAM data. Savings levels 
will vary with the level of economic activity. Enterprises receive income from capital and transfers from other institutions. They pay taxes, save and transfer income to other institutions but do not consume sectoral output. The government receives direct and indirect taxes and spends on sectoral consumption, savings and certain transfers. All transfers to households are fixed in nominal terms. The government expenditure is fixed and a compensatory tax by means of a direct tax is instituted. This tax adjustment handles any adjustments required to restore government revenues following a policy shock to ensure that a given government fiscal balance is achieved.

Table 1: Households endowment income shares in base year

\begin{tabular}{|l|c|c|c|c|c|}
\hline \multicolumn{7}{|c|}{ Endowment income source } \\
\hline Household type & unskilled labour & skilled labour & capital & land & Firm \\
\hline Communal farmers & $27.2 \%$ & $0.0 \%$ & $15.3 \%$ & $29.5 \%$ & $0.0 \%$ \\
\hline Farm workers & $3.3 \%$ & $0.0 \%$ & $0.0 \%$ & $0.0 \%$ & $0.0 \%$ \\
\hline Commercial farmers & $0.0 \%$ & $8.8 \%$ & $77.3 \%$ & $70.5 \%$ & $62.6 \%$ \\
\hline Urban unskilled households & $69.4 \%$ & $0.0 \%$ & $7.4 \%$ & $0.0 \%$ & $0.0 \%$ \\
\hline Urban skilled households & $0.0 \%$ & $91.2 \%$ & $0.0 \%$ & $0.0 \%$ & $37.4 \%$ \\
\hline Total & $\mathbf{1 0 0} \%$ & $\mathbf{1 0 0} \%$ & $\mathbf{1 0 0} \%$ & $\mathbf{1 0 0 \%}$ & $\mathbf{1 0 0} \%$ \\
\hline
\end{tabular}

Sectoral output is sold domestically or abroad. There is imperfect substitution between the export good and the domestic good. This imperfection is formulated using a constant elasticity of transformation (CET) specification. Similarly, there is imperfect substitution between the domestic good and imported goods modelled as a CES specification following Armington (1969). Imperfect substitutability allows for the existence of two-way trade in the same commodity as well as giving some measure of independence from external forces to domestic prices.

Model closure rules refer to macroeconomic adjustments in the model. The choice of closure rules has a huge influence on the results and as such they should be chosen with due care. We assume that the government budget deficit and volume of government current consumption are both fixed. A uniform change in household income tax and company tax rates ensures that government revenues adjust until the given budget deficit is attained. The assumption that the budget deficit is fixed ensures that the land reform is not financed simply by larger budget deficits. We also assume that the current account balance of payments is fixed so that the real exchange rate is the adjustment variable. Again this assumption is interpreted to mean that the land reform exercise is not financed by exogenous foreign currency inflows, which 
accords well with the observation that international aid ground to an almost complete halt during the fast track land reform. If it is intended that there will be such an inflow, either through aid or foreign investment, it would be possible to adjust the fixed foreign deficit to the anticipated amount. The assumption of fixed investment with variable savings helps us to rule out 'free lunch' outcomes where investment can be run down even to negative levels without there being any negative impact on welfare. Taken together, these closures are in line with those found in the Zimbabwean CGE literature (see for example Davies et al (1994), Chitiga and Mabugu (2005) and Bautista et al (1998) and they imply that our modelled counterfactual is very different to how the government chose to implement fiscal and trade policy during the fast track land reform exercise. The model is square in the sense that the number of equations is equal to the number of variables. The model was checked to verify that it is homogeneous of degree zero in prices. The nominal exchange rate is taken as the numéraire.

\section{Simulation results}

The paper simulates a land transfer of 40 per cent from commercial farmers to communal farmers. The total arable land is maintained at the same level as in the base year. This is very close to the actual shock that took place during the fast track land reform that started after 1997. To focus on the underlying resource allocation, poverty and macroeconomic issues, problems of mismanagement or wastage of land are assumed away.

Assuming that the land reform is well managed and targeted in this way, the land reform generates a significant increase in crops grown by communal farmers. Grain increases by 3.4 per cent compared to its base year value while horticultural crops such as beans and other vegetables increase by 1.5 per cent. Other crops and livestock also increase as does forestry. The main reason for the increase in these crops is due to increased demand by communal households whose incomes have increased. Communal farmers demand the majority of non export-oriented agricultural products whose supply is increasing. ${ }^{4}$ There is, on the other hand, a fall in the agricultural production of cotton and tobacco ( 0.5 per cent) and tea and coffee ( 0.4 per cent). The reason for this decline is because factors are pulled towards the production

\footnotetext{
${ }^{4}$ The SAM data includes formal and informal activities. In the case of forestry, note further that firewood and other forestry services such as fruit and herb collection are included. Communal farmers are the largest demanders of forestry product as a final commodity.
} 
of crops grown intensively by communal farmers and demanded by communal farmers and away from the export crops that are traditionally grown by the commercial farmers. As this expansion in agriculture takes place, it raises the economywide prices of factors of production. This increase in production costs hurts mildly the manufacturing and services sectors. Compounding this effect as well is that the falling agriculture sectors, particularly cotton, are the major input suppliers to the manufacturing sectors. Figure 1 shows the sectoral output changes of the land reform intervention.

Figure 1: Sectoral change in output

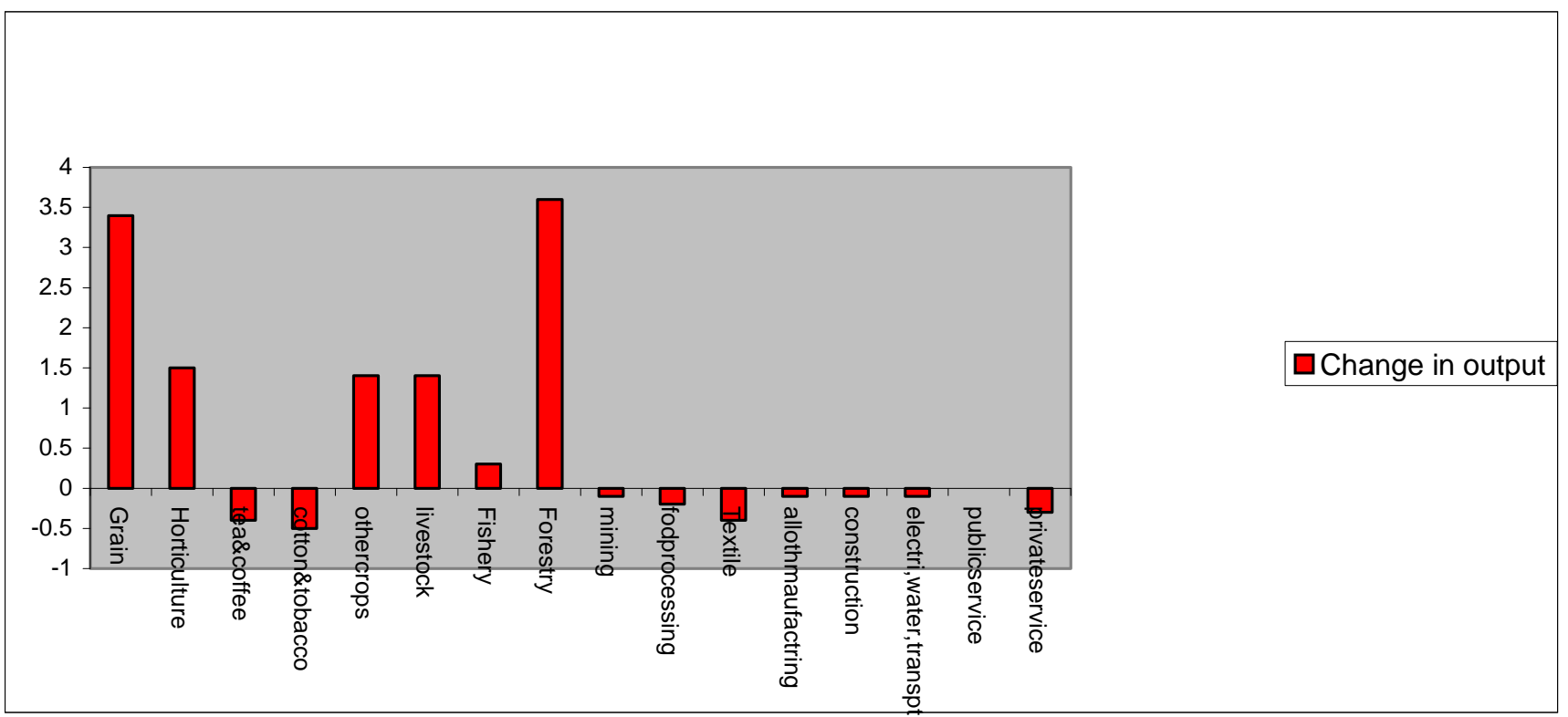

There is a fall in the total exports. This is mainly because the main export crops (tobacco, cotton, tea and coffee) are the direct casualties of the reform exercise. Coupled with this is the real exchange rate appreciation brought about by the increase in the consumer price index. The consequent fall in export revenues leads to a fall in the imports of commodities (the "no free lunch' condition implied by the closure rules). With falling supply in the main domestic market (manufacturing and services), all prices increase on the local market. The consumer price index increases for all households. The return to land improves in the whole economy while the return to capital falls. Although more capital is attracted in the sectors that are gaining, much more is shed off in the rest of the economy including the industrial sectors. The increase in agriculture by non-export sectors attracts more unskilled labour and their wages increase by 0.6 per cent. The fall in output and the increase in unskilled wage in turn 
lead to a fall in demand for unskilled labour in the industrial sectors. At the same time, the reduction in output in the industrial sectors leads to reduced demand for skilled labour, forcing its wage to fall by 0.2 per cent. The incomes of the communal farmers, (the beneficiaries of the land reform), increases substantially by about 8 per cent. As expected, the income of the commercial farmers falls but only by 1.7 per cent. This is because the initial land income to commercial farmers was far larger than that of communal farmers as seen in Table 1. Because of the increase in unskilled labour demand, all unskilled workers experience income increases. The farm workers experience an increase of 0.6 per cent and those unskilled income households in the urban areas experience gains of 0.5 per cent. The total income increases are not the same for all unskilled income earners even though there is free mobility of unskilled workers, which implies that unskilled wage rates are the same in equilibrium. This is because incomes for each group are influenced by other factors of production as well as different transfers so that initial factor shares in income play an important role. For instance, the income of urban unskilled households is additionally affected by capital income while that of farm workers is only affected by unskilled labour income. The initial income sources are affected differently for individual groups hence the different final income changes for each group.

The urban skilled income households who rely on capital and skilled labour income experience a fall in incomes of 0.2 per cent. There is also another, more subtle macroeconomic adjustment that is responsible for depressing incomes of the higher-income groups. Because of reduced economic activity, general tax revenue declines in the economy. However, because of the way the model is closed, there is an automatic compensation of lost revenue through increases in direct taxes, which fall disproportionately more on high-income households. Thus, skilled income earners and the commercial farm households are responsible for shouldering the burden imposed by the land reform on the fiscal deficit in the counterfactual.

To discuss the welfare effects of the intervention, use is made of the equivalent variation $(E V)$ concept. It is used to measure social welfare by comparing the utility of households at price and income in a reference situation to the utility in the new situation (see Varian 1992). Equivalent variation is defined as:

1.

$$
E V=\left(\frac{P_{1}^{0}}{P_{1}{ }^{1}}\right)^{\gamma}\left(\frac{P_{2}^{0}}{P_{2}^{1}}\right)^{1-\gamma}\left(Y M^{1}-Y M^{0}\right)
$$


where $P_{1}^{0}$ : price of good 1 in the base year (before simulation);

$P_{1}{ }^{1}$ : price of good 1 in year 1 (after simulation);

$P_{2}{ }^{0}$ : price of good 2 in the base year (before simulation);

$P_{2}^{1}$ : price of good 2 in year 1 (after simulation);

and: $\quad Y M^{0}$ : Household income in the base year (before simulation);

$Y M^{1}$ : Household income in year 1 (after simulation).

If: $\quad E V>0$ increase in household welfare;

$E V<0$ decrease in household welfare;

Table 2 shows that the communal farmers, farm workers and the urban unskilled households experience an increase in their welfare following a land reform. The other two households, however, see a fall in their welfare. Hence, the land redistribution is potentially pro-poor irrespective of the region where the poor reside.

Table 2: Welfare outcomes (per cent changes)

\begin{tabular}{|l|c|c|c|c|c|}
\hline & $\begin{array}{c}\text { Communal } \\
\text { farmers }\end{array}$ & $\begin{array}{c}\text { Farm } \\
\text { workers }\end{array}$ & $\begin{array}{c}\text { Commercial } \\
\text { farmers }\end{array}$ & $\begin{array}{c}\text { Urban } \\
\text { Unskilled } \\
\text { households }\end{array}$ & $\begin{array}{c}\text { Urban } \\
\text { Skilled } \\
\text { househo } \\
\text { lds }\end{array}$ \\
\hline Change in disposal income & 7.8 & 0.6 & -1.7 & 0.5 & -0.2 \\
\hline Change in total consumption & 7.8 & 0.6 & -1.7 & 0.5 & -0.2 \\
\hline Change in household consumer price & 0.3 & 0.3 & 0.2 & 0.2 & 0.1 \\
\hline Equivalent variation & 7.1 & 0.2 & -1.4 & 0.2 & -0.2 \\
\hline
\end{tabular}

With the aid of sequential microsimulation techniques, we are able to tell the extent of the change in poverty and inequality that occurs due to the 40 per cent land redistribution experiment. Using the new income, consumption and price changes from the CGE model for the five household types, we adjust each household in the microsimulation model's benchmark variables. These new variables are then used to compute poverty indicators using the Foster, Greer and Thorbecke (FGT) (1984) measures. ${ }^{5}$

\footnotetext{
${ }^{5}$ Poverty is decomposed into the poverty headcount (population below the poverty line), poverty gap and the severity of poverty. The FGT index is defined as:

$$
P_{\alpha}=\frac{1}{n} \sum_{i=1}^{q}\left[\frac{z-y_{i}}{z}\right]^{\alpha}
$$

Where $\mathrm{z}$ is the poverty line, $y_{i}$ is income for household $\mathrm{i}, \mathrm{n}$ is the total population, $\mathrm{q}$ is the number of the poor population and $\alpha$ is the degree of aversion to poverty. The poverty and inequality measures are computed using the software called DAD that was developed by Duclos et al (2002).
} 
The poverty headcount index gives the number of households below the poverty line divided by the total households in the group when the degree of aversion to poverty is zero. This shows the prevalence of poverty but does not give a good idea about the degree of poverty. Poverty depth informs on the mean shortfall of the poor's income below the poverty line. In this case the degree of aversion to poverty is set to unity and this enables calculation of the level of income transfer needed to bring all poor households to the poverty line. Lastly, a poverty severity index is computed that takes into account the inequality among households that are poor. In this case, the degree of aversion to poverty is set at two, meaning that more importance is accorded to the shortfalls of the poorest households. The weight assigned to each household is equal to its shortfall from the poverty line (see also Ravallion (1994)).

The poverty results are reported in Tables 3 and 4 in terms of the poverty gap, head count ratio and the poverty severity for each of the household types as well as for the whole economy. The poverty line used is the national total consumption poverty line of $Z \$ 1912.41$ in 1995 dollars (approximately USD232) as calculated by the PASS study (Government of Zimbabwe 1996). This policy leads to an overall decrease in poverty in the economy. This is the case for all FGT indices showing headcount ratios, the poverty gap and the poverty severity. The reduction in poverty in the country, however, is coming from the benefits accruing mainly to rural communities as a result of the land reform. This is because rural poverty falls substantially. Urban head count poverty slightly increases with the poverty gap and severity remaining essentially the same.

Table 3: Poverty results for the whole economy and for urban and rural areas

\begin{tabular}{|l|l|c|c|c|}
\hline \multirow{4}{*}{ All } & & $\begin{array}{l}\text { Before } \\
\text { simulation }\end{array}$ & $\begin{array}{l}\text { After } \\
\text { simulation }\end{array}$ & $\begin{array}{l}\text { Change } \\
\text { (per } \\
\text { cent) }\end{array}$ \\
\cline { 2 - 5 } & head count & 0.507 & 0.500 & -1.4 \\
\cline { 2 - 5 } & & $(0.00499)$ & $(0.00499)$ & \\
\cline { 2 - 5 } & Poverty gap & 0.245 & 0.241 & -1.6 \\
\cline { 2 - 5 } & & $(0.00299)$ & $(0.00297)$ & \\
\cline { 2 - 5 } & Poverty severity & 0.149 & 0.146 & -2.1 \\
\cline { 2 - 5 } & & $(0.00226)$ & $(0.00224)$ & \\
\hline \multirow{5}{*}{ Rural areas } & & & & \\
\cline { 2 - 5 } & head count & 0.535 & 0.525 & -1.9 \\
\cline { 2 - 6 } & & $(0.00615)$ & $(0.00616)$ & \\
\cline { 2 - 5 } & Poverty gap & 0.257 & 0.251 & -2.3 \\
\cline { 2 - 6 } & & $(0.00370)$ & $(0.00370)$ & \\
\cline { 2 - 5 } & Poverty severity & 0.155 & 0.151 & -2.6 \\
\hline
\end{tabular}




\begin{tabular}{|l|l|c|c|c|}
\hline & & $(0.00281)$ & $(0.00277)$ & \\
\hline \multirow{4}{*}{ Urban areas } & & & & \\
\cline { 2 - 5 } & head count & 0.443 & 0.444 & 0.2 \\
\cline { 2 - 5 } & & $(0.00838)$ & $(0.00838)$ & \\
\cline { 2 - 5 } & Poverty gap & 0.219 & 0.219 & 0.0 \\
\cline { 2 - 5 } & & $(0.00498)$ & $(0.00498)$ & \\
\cline { 2 - 5 } & Poverty severity & 0.135 & 0.135 & 0.0 \\
\cline { 2 - 5 } & & $(0.00349)$ & $(0.00374)$ & \\
\hline
\end{tabular}

Numbers in brackets are standard deviations

Table 4 gives the results for the individual groups. In the case of specific households, poverty falls for the households that get the land transfer (communal farmers) and increases for those who have their land reduced (the commercial farmers). This is the case for these two household groups in terms of the three FGT indices used. It is important to note that the communal farmers are the poorest group in the model. For farm workers the results are mild. Poverty gap and severity are reduced but the head count remains essentially the same. The urban unskilled households are also very slightly affected in terms of poverty reduction. The increase in income for these two groups is almost eroded by the increase in consumer prices resulting from lower industrial and services output so that there is a negligible impact on poverty. It must be pointed out that the poverty result for this group could have been worse had we assumed no mobility of factors of production between the rural and the urban sectors, as would be the case in the very short run. This would have meant that the benefits of increased unskilled labour demand and wages occurring due to the agricultural sector expansion would not have benefited urban unskilled workers. The assumptions in this model allows for a medium to long run interpretation of the outcomes. The urban skilled households experience an increase in poverty. This is mainly brought about in the model by the falling capital income, the increased direct tax bill required to compensate for government revenue shortfalls as well as the increasing consumer prices.

Table 4 Poverty results for the different groups

\begin{tabular}{|l|l|c|c|l|}
\hline Communal farmers & $\begin{array}{l}\text { Before } \\
\text { simulation }\end{array}$ & $\begin{array}{l}\text { After } \\
\text { simulation }\end{array}$ & $\begin{array}{l}\text { Change } \\
\text { (per } \\
\text { cent) }\end{array}$ \\
\cline { 2 - 5 } & head count & 0.552 & 0.520 & -5.8 \\
\hline & $(0.00924)$ & $(0.00923)$ & \\
\cline { 2 - 5 } & poverty gap & 0.270 & 0.2486 & -8.3 \\
\hline & & $(0.00552)$ & $(0.00537)$ & \\
\hline & poverty severity & 0.165 & 0.150 & -9.2 \\
\hline
\end{tabular}




\begin{tabular}{|c|c|c|c|c|}
\hline & & $(0.00420)$ & $(0.00411)$ & \\
\hline \multirow{6}{*}{ Farm workers } & head count & 0.627 & 0.630 & 0.0 \\
\hline & & $(0.08627)$ & $(0.08627)$ & \\
\hline & poverty gap & 0.293 & 0.292 & -0.3 \\
\hline & & $(0.05039)$ & $(0.05035)$ & \\
\hline & poverty severity & 0.173 & 0.173 & -0.4 \\
\hline & & $(0.04209)$ & $(0.04206)$ & \\
\hline \multirow{6}{*}{ Commercial farmers } & head count & 0.440 & 0.446 & 12 \\
\hline & & $(0.00980)$ & $(0.00981)$ & \\
\hline & poverty gap & 0.208 & 0.212 & 1.9 \\
\hline & & $(0.00691)$ & $(0.00610)$ & \\
\hline & poverty severity & 0.124 & 0.127 & 2.6 \\
\hline & & $(0.00399)$ & $(0.00412)$ & \\
\hline \multirow{6}{*}{ Urban unskilled households } & head count & 0.470 & 0.470 & 0.0 \\
\hline & & $(0.01319)$ & $(0.013191)$ & \\
\hline & poverty gap & 0.230 & 0.230 & 0.0 \\
\hline & & $(0.00800)$ & $(0.00800)$ & \\
\hline & poverty severity & 0.146 & 0.146 & -0.4 \\
\hline & & $(0.00605)$ & $(0.00604)$ & \\
\hline \multirow{6}{*}{ Urban skilled households } & head count & 0.423 & 0.425 & 0.5 \\
\hline & & $(0.01070)$ & $(0.01070)$ & \\
\hline & poverty gap & 0.208 & 0.209 & 0.5 \\
\hline & & $(0.00631)$ & $(0.00632)$ & \\
\hline & poverty severity & 0.127 & 0.128 & 0.3 \\
\hline & & $(0.00473)$ & $(0.00474)$ & \\
\hline
\end{tabular}

Numbers in brackets are standard deviations

Table 5 shows that in the general economy there is a fall in inequality using all the indices. ${ }^{6}$ This inequality reduction is coming from the fall in inequality that occurs in the rural areas.

\footnotetext{
${ }^{6}$ The Gini coefficient and Atkinson indices are used to measure inequality. The two indices range from 0 to 1 , with 0 indicating no inequality and 1 indicating perfect inequality. The Gini coefficient is computed as follows: Gini $=\frac{1}{\mu N(N-1)} \sum_{i} \sum_{j}\left|x_{i}-x_{j}\right|$ where $x$ is income (or consumption expenditure) of the household, $i$ and $j$ are households, $\mu$ is the mean income and $N$ is population. The Atkinson inequality index takes the following format:

$1-\frac{I_{e}}{\mu}$ where $I_{e}$ is the uniform income level which when received by all households leads to the same total welfare as the actual income distribution and $\mu$ is the prevailing mean income level. $I_{e}$ is computed as:
} 
This is not surprising given that the policy simulation reduced the wealth of the relatively well off rural households and transferred this to the poorer rural households. In the urban areas the policy does not change inequality significantly.

Table 5: Inequality measures

\begin{tabular}{|c|c|c|c|c|}
\hline \multirow{4}{*}{ Gini index } & & $\begin{array}{l}\text { Before } \\
\text { simulation }\end{array}$ & $\begin{array}{l}\text { After } \\
\text { simulation }\end{array}$ & $\begin{array}{l}\text { Change } \\
\text { (per } \\
\text { cent) }\end{array}$ \\
\hline & All & 0.603 & 0.602 & -0.2 \\
\hline & Rural & 0.616 & 0.614 & -0.2 \\
\hline & Urban & 0.571 & 0.571 & 0.0 \\
\hline \multirow{3}{*}{ Atkinson, $\mathrm{e}=0.5$} & All & 0.331 & 0.329 & -0.7 \\
\hline & Rural & 0.351 & 0.348 & -0.8 \\
\hline & Urban & 0.285 & 0.285 & 0.0 \\
\hline \multirow{3}{*}{ Atkinson, $\mathrm{e}=\mathbf{0 . 7 5}$} & All & 0.423 & 0.421 & -0.4 \\
\hline & Rural & 0.440 & 0.438 & -0.5 \\
\hline & Urban & 0.383 & 0.383 & 0.0 \\
\hline
\end{tabular}

Alternative simulations to try and see if there is a win-win situation in which incomes of communal farmers increase and those of commercial farmers also increase were explored. The results showed that to come close to such a situation, less land should be redistributed. Only 5 per cent land redistribution as opposed to 40 per cent would allow for an almost neutral result in the economy. Alternatively, taking away close to 7.6 per cent of the gained income from communal farmers and giving it directly to commercial farmers also allows for a situation of a very small income gain for communal farmers and a neutral income change for the rest of the household groups. Finally, one can conceive of win-win situations if the model closure rules are changed so that aid inflows or expansive budget deficits are allowed. However, as argued above, it is felt that these are not feasible ways of closing the Zimbabwean economy.

$$
I_{e}=\left[\sum_{i=1}^{n} f\left(I_{i}\right) I_{i}^{1-\varepsilon}\right]^{1 / 1-\varepsilon}
$$

where $I_{i}$ is the proportion of income earned by the ith group, $\varepsilon$ is the societal aversion to inequality parameter, with higher $\varepsilon$-values being associated with higher aversion. Both $\varepsilon$ values of 0.5 and 0.75 have been used to capture different levels of the society's aversion to poverty. 
Finally, the model is used to check the effects of an increase in the productivity of crops mainly grown by communal farmers after the land redistribution. The crops targeted were grain, horticulture, and other crops. These productivity increases are premised on the assumption that the new farmers would get training and be assisted with farming resources that they previously lacked. Such a simulation allows the gap in the change in income between the communal farmers and the commercial farmers to be reduced. This leads to a much lower reduction in inequality between these two groups. Further, such a simulation has adverse effects on unskilled labour that is used intensively in agriculture, as farmers use their land more efficiently. The incomes of farm workers and those of households reliant on unskilled labour income in the urban areas fall. On the other hand, skilled labour income households benefit from an increase in remuneration for skilled workers. The increased income of skilled workers and communal farm households leads to increased demand in the economy thereby leading to an increase in the general consumer prices. The increased prices add to the loss of unskilled labour income and farm workers. This outcome would clearly be undesirable from a poverty reduction point of view. The result illustrates that with such initiatives, it is inevitable that there are some losers.

\section{Conclusion}

Zimbabwe has suffered immensely as a result of a poorly orchestrated land reform process. After close to two decades of slow land reform, authorities embarked on a rapid land reform approaching the end of the 1990s. The fast track land reform was officially completed in 2002. Poverty rates and inequality have gone up substantially. This paper has used a CGE model coupled with a microsimulation model in order to quantify the impacts of land reform on poverty, inequality and economic activity. This, to our knowledge, is the first attempt at applying the microsimulation cum CGE methodology to the study of the impact of land reform on poverty in the context of an African country. The results for the land reform simulations show that it can result in substantial reductions in poverty, its severity and incidence as well as reducing income disparities. This is especially so for the household group that receives the redistributed land. Although these simulated effects are not what actually took place because they are based on a counterfactual, they are interesting because they give clues as to what could have happened if the reform had been handled differently. 
The main lesson from this exercise is that land reform can be an important tool to reduce poverty and inequality if new landowners are able to maintain their production capacity and fiscal and external balances are kept in check through relevant tax adjustment and real exchange rate adjustment. We also learn that there will be losers from this exercise, and compensatory mechanisms should be part of the land reform exercise. This is also true if some of the assumptions of the present model are relaxed such as the free mobility of factors. It may be that in the very short run more groups would need to be considered for compensation to shield them from the reforms. These lessons are not only valuable for Zimbabwe as and when the authorities attempt to correct some of the mistakes made in implementing the fast track land reform, but also for neighboring countries such as South Africa and to some extent Namibia as they attempt to find solutions to the pressing land distribution disparities that they face. 


\section{References}

Aghion, P, Caroli, E. and Garcia-Penalosa, C., (1999) "Inequality and Economic Growth: The Perspective of the New Growth Theories." Journal of Economic Literature, 37: 16151660

Armington, P., (1969) "A Theory of Demand for Products Distinguished by Place of Production.” IMF Staff Papers 16: 159-176.

Bautista, R.M. and Thomas, M., (2000) "Trade and Agricultural Policy Reforms in Zimbabwe: A CGE Analysis" Paper presented in $3^{\text {rd }}$ Annual Conference on Global Economic Analysis, June 2000. Available at:

www.monash.edu.au/policy/conf/71Thomas.pdf

Bautista, R., Lofgren, H. and Thomas, M., (1998) "Does Trade Liberalization Enhance Income Growth and Equity in Zimbabwe? The Role of Complementary Policies", TMD Discussion Paper No 32 Washington DC: IFPRI.

Birdsall, N. and Londono, J.L., (1997) "Asset Inequality Matters: An Assessment of the World Bank's Approach to Poverty Reduction." American Economic Association Papers and Proceedings 87: 32-37.

Burgess, T. and Beasly, R., (1998) Land Reform, Poverty Reduction and Growth: Evidence From India, Mimeo, London School of Economics.

Chiremba, S. and Masters, W., (2003) “The Experience of Resettled Farmers in Zimbabwe." African Studies Quarterly 7, no.2\&3: Avaivable at: http://web.africa.ufl.edu/asq/v7/v7i2a5.htm

Chitiga, M. Davies, R. and Mabugu, R., (2000) A 1995 Social Accounting Matrix (SAM) for Zimbabwe, Mimeo., SIDA Office in Harare, Zimbabwe.

Chitiga, M. (2000) "Distribution Policy under Trade Liberalisation in Zimbabwe: A CGE Analysis", Journal of African Economies, 9: 101-131.

Chitiga, M. and Mabugu, R., (2005) "The Impact of Tariff Reduction on Poverty in Zimbabwe: A CGE Top-Down Approach", South African Journal of Economic and Management Sciences, 8: 102-116

Christiansen, R,E., (1993) "Implementing Strategies for the Rural Economy: Lessons from Zimbabwe, Options for South Africa." World Development, 21: 1549-1566.

CIA (Central Intelligence Agency)(2007), World Fact Book 2007: Zimbabwe, Available at https://www.cia.gov/library/publications/the-world-factbook/geos/zi.html

CIA (Central Intelligence Agency) (2004), World Fact Book 2004: Zimbabwe, Available at http:/www.answers.com/topic/cia-world-fact-book-2004-zimbabwe

CIA (Central Intelligence Agency) (1998), World Fact Book 1998: Zimbabwe, Available at http://www.umsl.edu/services/govdocs/wofact99/316.htm 
Cockburn, J., Decaluwé, B. and Robichaud, V., (2004) "Trade liberalization and poverty: A CGE analysis of the 1990s experience", Poverty and Economic Policy Network, TM.

Cockburn, J. and Cloutier, M-H., (2002) "How to Build an Integrated CGE Microsimulation Model: Step-by step Instructions with an Illustrative Exercise. Equilibrium Microsimulation Analysis“, PEP working paper Available at: www.PEP-NET.ORG/

Cockburn, J., (2001) "Trade Liberalization and Poverty in Nepal: A Computable General Equilibrium Microsimulation Analysis". CREFA working paper (01-18). Available at: www.crefa.ecn.ulaval.ca/cahier/0118.pdf

Corroraton, B., (2003) "Analysis of Trade Reforms, Income Inequality and Poverty Using Microsimulation Approach: The case of the Philippines", PIDS Discussion Paper Series NO. 2003-09.

Davies, R., (2004) "Memories of Underdevelopment: A Personal Interpretation of Zimbabwe's Economic Development". Available at:

www.sarpn.org.za/documents/ d0001154/P1273-davies_zimbabwe_2004.pdf

Davies, R., Rattsø, J. and Torvik, R., (1994) "The Macroeconomics of Zimbabwe in the 1980's: A CGE-Model Analysis.” Journal of African Economies 3: 153-198.

Davies, R., Rattsø, J. and Torvik, R. (1998) "Short-run Consequences of Trade Liberalization in Zimbabwe: A CGE-Model Analysis.” Journal of Policy Modeling 20: 305-333.

Decaluwé, B., Dumont, J-C. and Savard, L., (1999) "Measuring Poverty and Inequality in a Computable General Equilibrium Model". Working Paper 99-20 CREFA, University of Laval.

Deninger, K. and Squire, L., (1998) "New Ways of Looking at Old Issues: Inequality and Growth." Journal of Developmental Economics 57: 257-285.

Deninger, K., Lara, F., Maertens, M., and Olinto, P., (2000) "Redistribution, Investment and Human Capital Accumulation: The case of Agrarian Reform in the Philippines". World Bank's Annual Conference on Developmental Economics, Washington DC.

Duclos J., Araar, A. and Fortin, C., (2002) DAD4.3: Distributive Analysis. Laval University.

Foster J., Greer, J. and Thorbecke, E., (1984) "A Class of Decomposable Poverty Measures. Econometrica", 52: 761-766.

Government of Zimbabwe (1996) 1995 Poverty Assessment Study Survey (PASS) Main Report, (Ministry of Public Services, Labour and Social Welfare), Harare.

Juana, J. and Mabugu, R., (2005) “Assessment of Smallholder Agriculture's Contribution to the Economy of Zimbabwe: A Social Accounting Matrix Multiplier Analyses", Agrekon, 44: 344-362

Mabugu, R. (2001) "Short run Effects of Tariff Reform in Zimbabwe: Applied General Equilibrium Analysis". Journal of African Economies, 10: 174-190 
Matshe, I., (2004) "The Overall Macroeconomic Environment and Agrarian Reforms", Mimeo. African Institute for Agrarian Studies.

Moyo, S., (1995) The Land Question in Zimbabwe, Harare: SAPES Books.

Moyo, S., (2004) "The Land and Agrarian Question in Zimbabwe", Paper presented at the conference: Conference on 'The Agrarian Constraint and Poverty Reduction: Macroeconomic Lessons for Africa', Addis Ababa, 17-18 December, 2004.

Moyo, S. and Yeros, P., (2004) "Land Occupations and Land Reform in Zimbabwe: Towards the National Democratic Revolution". In S. Moyo and Yeros, P., (Eds) Reclaiming the Land: The Resurgence of Rural Movements in Africa, Asia and Latin America. London, Zed Books.

OECD, (2003) "Zimbabwe", In OECD (2003), Africa Economic Outlook, available at: http://www.oecd.org

Rattsø, J. and Torvik, R., (1998) "Trade Liberalization in Zimbabwe: Ex post Evaluation", Cambridge Journal of Economics, 22: 325-346.

Ravaillon, M., (1994) Poverty Comparisons. Harwood Academic Publisher.

Rukuni, M., (1991) “The Evolution of Zimbabwe’s Agricultural Policy 1890-1990”. Paper prepared for the Conference on Zimbabwe's Agricultural Revolution, Harare, Zimbabwe.

Varian, H.R., (1992) Microeconomic Analysis. W. W. Norton \& Company, Inc.

World Bank (2001) World Development Report 2000/2001, Attacking Poverty, Oxford, Oxford University Press.

Zimconsult (2004) Famine in Zimbabwe: Implications of 2003/04 Cropping season, A consultancy report prepared for the Friedrich Ebert Stiftung. 